\title{
IDENTIFIKASI BAKTERI RESISTEN MERKURI PADA INDIVIDU DI DAERAH PESISIR PANTAI DI DESA BUDOKECAMATAN WORI
}

\author{
Jefry Hamonangan Hinonaung \\ Widdhi Bodhi \\ Billy Kepel
}

\author{
Bagian Kimia Fakultas Kedokteran Universitas Sam Ratulangi \\ Jefryhinonaung10.163@gmail.com
}

\begin{abstract}
Mercury is a silver liquid element at room temperature. Mercury form a variety of both inorganic and organic compounds. Mercury that goes into the sea, there is evaporated back into the atmosphere and fall to the ground experiencing methylation. Mercury in water can undergo methylation area with the help of the sulfate reducing bacteria and iron. Not only mercury from only rainwater but sediment mercury in the bottom waters can also be converted into methyl mercury. MeHg is harmful to humans, because it will accumulate $\mathrm{MeHg}$ in plankton or microorganisms. Then the plankton and microorganisms will be eaten by predators higher up the food chain in consumption by humans. This tudy aims to determine determine mercury resistant bacteria found in individuals in the coastal areas. The study design was a descriptive exploratory method. Samples taken in this study was a colony of mercury -resistant bacteria in tartar, urine and feces. Specimens were obtained put in a sterile pot and immediately brought to the biology laboratory in the MIPA Unsrat Manado Faculty to the identification of mercury -resistant bacteria and test. Isolation of mercury resistant bacterial isolates in 3 samples, obtained 6 isolates. Then test to identify bacteria with morphological, physiological testing, and biochemical testing. Results of a study found four genus of bacteria.
\end{abstract}

Keywords: Mercury , Mercury Resistant Bacteria , Tartar , Urine , Feces

\begin{abstract}
Abstrak:Merkuri merupakan suatu unsur berbentuk cair keperakan pada suhukamar. Merkuri membentuk berbagai persenyawaan baik anorganikmaupun organik. Merkuri yang masuk ke dalam laut, ada yang menguap kembali ke atmosfir dan jatuh ke tanah mengalami metilisasi. Merkuri dalam daerah perairan dapat mengalami metilisasi dengan bantuan bakteri pereduksi sulfat dan besi. Tidak hanya merkuri dari air hujan saja tetapi sedimen merkuri di dasar perairan juga dapat diubah menjadi metil merkuri. MeHg ini berbahaya bagi manusia, karena $\mathrm{MeHg}$ ini akan terakumulasi dalam plankton atau mikroorganisme. Kemudian plankton dan mikroorganisme ini akan di makan oleh predator yang lebih tinggi lagi dalam rantai makanan hingga di konsumsi oleh manusia. Penelitian ini bertujuan untuk mengetahui mengetahui bakteri resisten merkuri yang terdapat pada individu di daerah pesisir pantai. Desain penelitian adalah metode deskriptif eksploratif. Sampel yang diambil dalam penelitian ini adalah koloni bakteri resisten merkuri pada karang gigi, urin dan feses. Spesimen yang didapatkan dimasukkan ke dalam pot steril dan segera di bawa ke laboratoriumbiologi Fakultas MIPA Unsrat Manado untuk dilakukan identifikasi bakteri dan uji resisten merkuri. Isolasi isolat bakteri resisten merkuri pada 3 sampel, diperoleh 6 isolat. Kemudian dilakukan identifikasi bakteri dengan uji morfologi, uji fisiologi, dan uji biokimia. Hasil peneltian ditemukan 4 genus bakteri.
\end{abstract}


Merkuri merupakan suatu unsur berbentuk cair keperakan pada suhukamar. Merkuri membentuk berbagai persenyawaan baik anorganik maupun organik. Jika merkuri dikonsumsi atau meresap dalam tubuh manusia, bahayanya cukup besar. Gejala-gejala seperti tidak berfungsinya otak, ginjal, tremor, rasa gelisah atau gugup, insomnia, gangguan fungsi paru-paru, memperlambat pertumbuhan janin, hingga kerusakan liver pada kelahiran. Jika terjadi keracunan merkuri akan timbul manifestasi pada rongga mulut seperti ulserasi membran mukosa, pembengkakan lidah, perubahan warna gusi, dan stomatitis sampai gigi bergoyang. ${ }^{1,2}$

Merkuri yang masuk ke dalam laut, ada yang menguap kembali ke atmosfir dan jatuh ke tanah mengalami metilisasi. Merkuri dalam daerah perairan dapat mengalami metilisasi (MeHg) dengan bantuan bakteri pereduksi sulfat dan besi. Tidak hanya merkuri dari air hujan saja tetapi sedimen merkuri di dasar perairan juga dapat diubah menjadi metil merkuri. MeHg ini berbahaya bagi manusia, karena $\mathrm{MeHg}$ ini akan terakumulasi dalam plankton atau mikroorganisme. Kemudian plankton dan mikroorganisme ini akan di makan oleh predator yang lebih tinggi lagi dalam rantai makanan hingga di konsumsi oleh manusia. ${ }^{3}$

Dalam tubuh manusia terdapat bakteri yang resisten terhadap merkuri. Walaupun terpapar secara kronis oleh merkuri yang terbawah bersama hasil laut, seperti ikan yang kemudian di konsumsi oleh manusia. Tetapi tidak menimbulkan gejala-gejala keracunan merkuri. Karena bakteri ini dapat mendetoksifikasi merkuri dengan mengubah bentuk $\mathrm{Hg}^{2+}$ yang memiliki sifat toksik menjadi bentuk $\mathrm{Hg}^{0}$ yang bersifat volatile dan tidak toksik di bandingkan dengan bentuk $\mathrm{Hg}^{2+}$. Bakteri ini memiliki seperangkat gen mer operon, sehingga mampu mengubah bentuk merkuri yang bersifat toksik menjadi tidak toksik. ${ }^{3}$

\section{METODE PENELITIAN}

Penelitian ini bersifat deskriptif eksploratif. Penelitian ini dilakukan di Laboratorium Biologi Fakultas MIPA Universitas Sam Ratulangi Manado sejak November 2013 sampai Januari 2014.

Penelitian ini dilakukan dengan beberapa tahap, yaitu tahapn isolasi bakteri resisten merkuri dimana bertujuan untuk mengisolasi bakteri-bakteri yang ada pada sampel karang gigi, urin dan feses. Cara kerjanya, koloni ditumbuhkan pada media Nutrient Agar yang sudah mengandung merkuri setelah perhitungan total koloni, kemudian dipindahkan pada media agar miring dengan menggunakan jarum ose sebagai kultur sediaan (isolat) dan selanjutnya disimpan pada suhu $40^{\circ} \mathrm{C}$. Setelah itu dilakukan seleksi kultur bakteri, seleksi ini dilakukan dengan cara inokulasi kultur bakteri sampel dalam media seleksi padat yang mengandung $\mathrm{HgCl}_{2}$ dengan konsentrasi 10, 20, dan $40 \mathrm{ppm}$ dan fenil merkuri dengan konsentrasi 5, 10, 20 ppm kemudian diinkubasi pada temperatur $37^{\circ} \mathrm{C}$ selama 24 jam. Selanjutnya diamati jumlah koloni yang tumbuh.

Selanjutnya dilakukan uji morfologi dengan pewarnaan gram. Tahap-tahap dalam penentuan gram bakteri sebagai berikut, kaca objek dibersihkan dengan kapas yang telah diberi alkohol lalu diberi label. Biakan bakteri pada nutrien agar miring diambil dengan menggunakan jarum ose, kemudian ditotol pada bagian tengah kaca objek samapi merata. Preparat selanjutnya difiksasi di atas lampu spritus dan diberikan larutan Kristal violet dan dibiarkan selama 1 menit, lalu dicuci dengan aquades dan di keringkan dengan tissu. Kemudian ditetes dengan larutan lugol, biarkan selama 30 detik, kemudian bilas dengan alkohol, lalu dicuci ulang dengan aquades dan keringkan dengan tissu (jangan digosok). Kemudian diberi larutan safranin selama 30 detik dan kembali dicuci dengan aquades dan keringkan ualng dengan tissu. Preparat yang telah diberi minyak imerasi diperiksa pada mikroskop dengan pembesaran 1000 kali. Hasil pengamatan dicatat kemudian difoto. Bakteri 
yang tetap bewarna ungu meskipun disertai pewarnaan oleh zat warna kontras merupakan bakteri gram positif. Sedangkan bakteri yang berwarna merah muda, merupakan bakteri gram negatif.Prosedur untuk uji fisiologi yaitu, disiapkan media Motility Test Medium dan dimasukkan ke dalam tabung yang telah diberi label sesuai kode biakan bakteri yang akan digunakan sebanyak $5 \mathrm{ml}$. kemudian media disterilkan pada suhu $121^{0} \mathrm{C}$ selama 15 menit, kemudian didinginkan. Setelah media sudah dingin, kemudian kultur sediaan diinkulasikan dengan tusukkan jarum ose sampai ke dasar media, kemudian pada suhu $37^{\circ} \mathrm{C}$ selama $24-48$ jam. Lakukan pengamatan setelah 24-48 jam masa inkubasi. Hasil positif apabila terlihat adanya pertumbuhan melebar dari bekas tusukan jarum ose. Kemudian dilakukan uji biokimia yang terdiri dari uji indol, uji $\mathrm{H}_{2} \mathrm{~S}$, uji sitrat, uji katalase, uji fermentasi karbohidrat, uji lisin dekarboksilase. Cara kerja uji indol sebagai berikut, isolat diinokulasikan ke tabung semi padat (Motility Test Medium) dengan koloni biakan yang berasal dari masing-masing agar miring dengan cara ditusukkan jarum sedalam $3 / 4$ bagian. Diinkubasi pada suhu $35^{\circ} \mathrm{C}$ selama 24 jam,dengan menambahkan 0,2-0,3 ml reagen covac's. Hasil indol positif apabila kultur berwarna merah pada saat penambahan reagen. Prosedur kerja uji $\mathrm{H}_{2} \mathrm{~S}$ sebagai berikut, disiapkan media Triple Sugar Iron (TSI), inokulasi bakteri dengan cara digores lalu ditusuk pada media. Diinkubasi pada suhu $37^{\circ} \mathrm{C}$ selama 24-48 jam. Hasil positif bila terbentuk warna hitam pada media berarti bakteri tidak mampu membentuk $\mathrm{H}_{2} \mathrm{~S}$ tapi bila terbentuk warna kuning berarti bakteri mampu membentuk $\mathrm{H}_{2} \mathrm{~S}$ dan uji bersifat negatif. Prosedur kerja, uji sitrat sebagai berikut, disiapkan media Simmon's Citrate Agar dan diberi label sesuai dengan kode biakan bakteri, dimana tabung berada pada posisi miring. Inokulasi secara aseptik biakan pada media dengan cara permukaan agar digores. Kemudian diinkubasi pada suhu $37^{0} \mathrm{C}$ selama 24-48 jam. Dilakukan pengamatan. Hasil positif bila terjadi perubahan warna media dari hijau menjadi biru dan uji bersifat negatif bila tidak terjadi perubahan warna pada media. Prosedur kerja uji katalase sebagai berikut, pertama dibuat media Nutrient Broth kemudian dimasukkan ke dalam tabung reaksi sebanyak $5 \mathrm{ml}$. kemudian kultur sediaan diinokulasi ke dalam tabung reaksi yang berisi Nutrient Broth. Selanjutnya diinkubasi pada suhu $37^{\circ} \mathrm{C}$ selama 24-48 jam. Selanjutnya ditambahkan 3-4 tetes 3\% hydrogen peroksida ke dalam kultur biakan. Hasil pengamatan dicatat berdasarkan gelembung udara di dalam tabung reaksi. Bila terjadi pembentukan gelembung udara, maka uji ini bersifat positif. Prosedur kerja uji Fermentasi Karbohidrat sebagai berikut, dibuat media Triple Sugar Iron Agar (TSIA) seperti pada uji $\mathrm{H}_{2} \mathrm{~S}$, kemudian dimasukkan ke dalam tabung Hach sebanyak $6 \mathrm{ml}$. setelah itu media disterilisasi pada suhu $121^{\circ} \mathrm{C}$ selama 15 menit, lalu diletakkan pada posisi miring sampai media dingin. Setelah media tersebut menjadi dingin, secara aseptic setiap isolat bakteri diinokulasi dengan jarum inokulasi lurus dengan cara ditusuk pada bagian tengah sampai kedalaman $3 / 4$ bagian dari permukaan media dan setelah itu digores pada bagian miring (slant) dari media, kemudian diinkubasi selama 24 jam pada suhu $37^{\circ}$ C.kemudian diperiksa apakah ada fermentasi karbohidrat dengan melihat pembentukan asam dan gas. Pembentukan asam terlihat sebagai perubahan warna substrat karbohidrat dari warna merah menjadi kuning. Pembentukan gas terlihat dalam tabung Durham. Bila mikroorganisme hanya dapat memfermentasikan glukosa, maka bagian butt media akan berwarna kuning (bersifat asam) dan bagian slant-nya akan berwarna merah (bersifat basa). Bila mikroorganisme dapat memfermentasikan laktosa atau sukrosa atau keduanya, maka bagian slant dan butt media akan berwarna kuning (bersifat asam) serta bagian butt media kadangkala terpecah akibat pembentukan gas seperti $\mathrm{H}_{2}$ dan $\mathrm{CO}_{2}$. Prosedur kerja uji lysin Dekarboksilase sebagai berikut, disiapkan media Lysin Iron Agar lalu sebanyak $6 \mathrm{ml}$ media dimasukkan kedalam tabung Hach. Media disterilkan dengan autoclave pada suhu $121^{\circ} \mathrm{C}$ selama 15. Setelah disterilkan, media dibuat menjadi agar miring. Kemudian bakteri diinokulasikan dengan cara ditusukan dan di goreskan pada media LIA miring. Diinkubasi pada suhu $37^{\circ} \mathrm{C}$ selama 24 jam. Reaksi positif ditunjukkan dengan perubahan warna pada 
media menjadi warna lembayung, sedangkan reaksi negatif ditandai dengan warna kuning pada media.

Setelah dilakukan uji Morfologi, Fisiologi, dan uji Biokimia, maka data dikumpulkan dalam tabel kemudian hasil ini dibandingkan dengan petunjuk yang terdapat dalam Bergey's Manual Determinative of Bacteriology.

\section{HASIL DAN PEMBAHASAN}

Hasildari isolasi bakteri resisten merkuri didapatkan pada konsentrasi $\mathrm{HgCl}_{2} 10 \mathrm{ppm}$ bakteri tumbuh dengan baik pada semua isolat. Pada konsentrasi $\mathrm{HgCl}_{2} 20$ ppm bakteri tumbuh dengan baik pada semua isolate. Pada konsentrasi $\mathrm{HgCl}_{2} 40 \mathrm{ppm}$ masih terdapat pertumbuhan bakteri tetapi sudah mulai sedikit bakteri yang tumbuh pada semua isolat.Pada konsenstrasi Fenil Merkuri 5 ppm bakteri tumbuh dengan baik pada semua isolat. Pada konsentrasi Fenil Merkuri 10 ppm bakteri tumbuh dengan baik pada semua isolat. Pada konsentrasi Fenil Merkuri 20 ppm Masih terdapat pertumbuhan bakteri tetapi sudah mulai sedikit bakteri yang tumbuh pada semua isolat. Yang di ambil adalah bakteri yang tumbuh pada konsentrasi $\mathrm{HgCl}_{2} 40$ ppm, dan Fenil Merkuri 20 ppm.

Identifikasi bakteri resisten merkuri yang dilakukan dengan teknik uji fisiologi, morfologi dan uji aktivitas biokimia. Setelah bakteri diisolasi dalam enam isolat, maka segera dilakukan identifikasi terhadap bakteri di tiap isolat tersebut.

Isolat j.f 40 menunjukkan gambaran kokus Gram negatif yang motil dengan hasil uji indol positif, katalase positif, fermentasi glukosa, uji sitrat negatif dan uji lisin positif. Dengan melihat karakteristik dari hasil pengujian, bakteri ini mirip dengan Enterococcus. Enterococcus merupakan bakteri anaerob fakultatif yang dapat tumbuh optimal pada suhu $35^{\circ} \mathrm{C}$ dan sering ditemukan di saluran pencernaan, saluran kemih dan juga dapat berkoloni di rongga mulut manusia.

Isolat j.u 40 menunjukkan gambaran basil Gram negatif. Pada uji motil didapatkan bakteri ini tidak motil, hasil katalase negatif, uji indol negatif, dapat memfermentasi glukosa tanpa menghasilkan gas dan tidak menghasilkan $\mathrm{H}_{2} \mathrm{~S}$. Uji sitrat negatif dan uji lisin positif. Dengan demikian hasil didapatkan dari seluruh percobaan ini, karakteristik bakteri yang ada pada isolat j.u 40 cocok dengan Bacillus sp.Bacillus sp. bersifat aerobik tapi juga dapat bersifat fakultatif anaerob. Metabolisme dengan fermentasi dan respirasi. Biasanya banyak terdapat di permukaan tanah, debu dan susu.

Isolat j.g 40 menunjukkan gambaran kokus Gram negatif yang motil dengan hasil uji katalase positif, uji indol positif, dapat memfermentasi glukosa dan terdapat pembentukan gas. Pada $\mathrm{Uji}_{2} \mathrm{~S}$ menunjukkan hasil negatif dan pada uji sitrat dan lisin menunjukkan hasil positif. Dari semua hasil yang telah di uji, maka dapat disimpulkan bahwa bakteri pada isolat j.g 40 adalah Streptococcus sp.Streptococcus sp dapat menghasilkan asam laktat. Bakteri ini banyak ditemukan di rongga mulut karena bakteri ini juga merupakan flora normal yang terdapat di mulut. Streptococcus sp merupakan bakteri penyebab awal proses karies gigi.

Hasil yang didapatkan pada penelitian ini sama dengan hasil penelitian yang didapatkan oleh Karen pada plak gigi pasien dengan tumpatan amalgam di Puskesmas Bahu, dimana didapatkan dari 15 jenis isolat yang memiliki kemampuan mereduksi merkuri, dimana Micrococcus, Staphylococcus, Acitenobacter, Alcaligenes, Brucella, Morococcus, Phenylobacterium dan salah satunya adalah Streptococcus merupakan 8 genus bakteri yang resisten merkuri. ${ }^{4}$

Isolat j.u fm 20 dan j.f fm 20 menunjukkan gambaran bakteri E.coli. dari pewarnaan Gram yang sama yaitu kokus Gram negatif. Keduanya juga tidak motil. E.coli merupakan 
bakteri aerob tapi juga bisa bersifat fakultatif anaerob. Pada uji katalase positif, uji indol negatif, dapat memfermentasi glukosa dan menghasilkan gas. Tidak menghasilkan $\mathrm{H}_{2} \mathrm{~S}$. padauji sitrat dan lisin didapatkan hasil positif. E.coli merupakan bakteri yang resisten terhadap panas, media tumbuh optimum yaitu $30-37^{0} \mathrm{C} .^{5}$

Pada uji resistensi menunjukkan bahwa bakteri Enterococcus, Bacillus sp. dan Streptococcus sp. masih dapat hidup pada konsentrasi $\mathrm{HgCl}_{2} 40 \mathrm{ppm}$ walaupun pertumbuhannya lebih lambat jika dibandingkan dengan pertumbuhan bakteri pada media yang kada $\mathrm{HgCl}_{2} 10$ ppm, sedangkan bakteri Bacillus sp. dan E.coli dapat hidup dengan baik pada konsentrasi fenil merkuri 5 ppm dan 10 ppm tetapi ketika konsentrasi fenil merkuri di naikkan menjadi 20 ppm bakteri tumbuh lebih lambat.

Hasil yang didapatkan ini berbeda dengan hasil yang ditemukan oleh Nofiani dan Gusrizal yang mendapatkan 24 isolat bakteri yang tahan terhadap $\mathrm{HgCl} 210$ ppm.

Berdasarkan karakter mikroskopis, makroskopis dan 13 karakter biokimia yang diuji, ke-24 isolat bakteri tersebut cenderung masuk ke dalam 9 genus yang berbeda, salah satunya adalah bacillus. $^{6}$

Setiap bakteri memiliki tingkat resistensi terhadap merkuri yang berbeda-beda, tergantung dari gen mer operon yang terdapat pada bakteri tersebut atau bisa juga karena perbedaan waktu terpapar merkuri yang berbeda dari tiap bakteri yang terdapat pada manusia. Semakin lama waktu terpapar merkuri maka kemampuan bakteri untuk mendetoksifikasi merkuri juga semakin meningkat, karena bakteri sudah bisa beradapatasi dengan merkuri. Tingkat resistensi juga bisa tergantung dari jumlah dari bakteri tersebut, semakin banyak bakteri yang ada kemungkinan tingkat resistensinya juga meningkat sehingga bisa didapatkan bakteri tersebut masih dapat bertahan pada konsentrasi $\mathrm{HgCl}_{2}$ diatas $40 \mathrm{ppm}$ dan konsentrasi fenil merkuri diatas 20 ppm.

\section{KESIMPULAN DAN SARAN}

Berdasarkan hasil penelitian yang didapatkan pada 6 isolat ditemukan empat jenis bakteri resisten merkuri pada sedimen karang gigi, feses, urin yaitu Enterococcus, Bacillus sp, Streptococcus sp, E.coli. Hasil uji resistensi terhadap merkuri didapatkan 3 bakteri yang dapat bertahan sampai pada konsentrasi $\mathrm{HgCl} 240$ ppm yaitu Enterococcus, Bacillus sp dan Streptococcus sp. Pada konsentrasi Fenil Merkuri 20 ppm terdapat 2 bakteri yang dapat bertahan hidup yaitu Bacillus sp , E.coli.

Dalam penelitian perlu diajukan saran yaituuntuk melakukan uji resistensi bakteri terhadap merkuri harus dilakukan secara periodik agar bisa mendapatkan bakteri yang lebih banyak lagi yang mungkin tidak teridentifikasi pada penelitian ini dan sebaiknya penelitian ini dilanjutkan ke tingkat molekuler untuk dapat membantu upaya detoksifikasi terhadap merkuri.

\section{UCAPAN TERIMA KASIH}

Ucapan terima kasih kepada Widdhi Bodhi, S.Si, M.Kes, Apt dan DR. dr. Billy J Kepel, M.Med, Sc dan semua pihak yang secara langsung maupun tidak langsung telah menumbuhkan ide atau gagasan dalam pemikiran penulis sehingga dapat menyelesaikan artikel ini.

\section{DAFTAR PUSTAKA}


1.Sitohang, Y. Karya tulis ilmiah sarjana. Identifikasi Isolat Bakteri Resisten Merkuri pada Media Kultur Awal yang Mengandung Merkuri di Kelurahan Ketang Baru, Kota Manado. Fakultas kedokteran Universitas Sam Ratulangi. 2011:11-13.

2. Subandri, S. Kajian Beban Pencemaran Merkuri Terhadap Air Sungai Menyuke dan Gangguan Kesehatan pada Penambang Sebagai Akibat Penambangan Emas Tanpa Izin (PETI) di Kecamatan Menyuke Kabupaten Landak Kalimantan Barat. Proposal Tesis Universitas Diponegoro Semarang. 2008.

3. Selin, N. Global Biogeochemical Cycling of Mercury. Massachusetts Institute of Technology. Cambridge. 2009. Vol 34: 43-63.

4. Mogi, K. Karya tulis ilmiah sarjana. Bakteri Resisten Merkuri (Hg) Pada Plak Gigi Pasien Dengan Tumpatan Amalgam di Puskesmas Bahu. Fakultas Kedokteran Universitas Sam Ratulangi. 2013.

5. Yean C. 2008. Development Of A Dna-Based Molecular Method For The Rapid Detection Of Enterococcus Species And Antimicrobial Resistance Genotypes. Universiti Sains Malaysia. 2008:1-24

6. Nofiani, R, Gusrizal. Bakteri Resisten Merkuri Spektrum Sempit dari Daerah Bekas Penambangan Emas Tanpa Izin (PETI) Mandor, Kalimantan Barat. Jurusan Kimia, FMIPA, Universitas Tanjung, Pontianak 78124. Pubished 03-03-2004. 